Open Access

\title{
Challenges and opportunities of innovation and incubators as a tool for knowledge- based economy
}

Hanadi Mubarak Al-Mubaraki and Michael Busler

*Correspondence:
dralmubaraki@live.com
Kuwait University, Kuwait City,
Kuwait

\begin{abstract}
Objectives: The purpose of this research is to analyze and identify the challenges and opportunities of innovation and incubators programs and their potential use worldwide.

Prior work: Discussed innovation and incubators as a powerful tool for knowledgebased economy from different perspectives using different criteria to measure the key performance indicators of best practices for innovation in the United States (US), United Kingdom (UK), and Gulf Cooperation Council States (GCC). The results are part of the ongoing research project funded by a grant from the Kuwait Foundation for Advancement of Sciences (KFAS-2012-1103-01).
\end{abstract}

Approach: The methodology is based on quantitative approach (survey questionnaire) and literature review.

Results: This paper provides several recommendations for the international implementation of innovation and incubators outcomes.

Implications: This paper provides value-added knowledge for both academics and practitioners who are interested in the successful adaptation of innovation and incubators.

Value: The authors believe that this paper demonstrates an added value to the current literature on innovation and incubators and fills the gap in the case studies in the literature of developed and developing countries and presents a more comprehensive analysis of progress and challenges to knowledge-based economies.

Keywords: Innovation, Incubators, Technology transfer, Developed countries, Knowledge-based economy, Quantitative

\section{Background}

Most popular international organizations include United States (US) National Business Incubator Association (NBIA, 2007), United Kingdom UK Business Incubation (UKBI, 2007), InfoDev-an arm of the World Bank Group (InfoDev, 2009), Organisation for Economic Cooperation and Development (OECD, 1997), The European Business and Innovation Network, and European Commission (EC 2002) focused on the execution of incubation and innovation programs to strengthen the successful growth of economic and social development.

(c) The Author(s). 2017 Open Access This article is distributed under the terms of the Creative Commons Attribution 4.0 International License (http://creativecommons.org/licenses/by/4.0/), which permits unrestricted use, distribution, and reproduction in any medium provided you give appropriate credit to the original author(s) and the source, provide a link to the Creative Commons license, and indicate if changes were made. 
Several research studies on incubators have been defined. The Business and Innovation Center is a physical place aimed at economic development through supporting start-up companies and their business development as well as existing small and medium companies (InfoDev, 2009). There are other definitions for business incubation as effective talent links, technology transfer organizations, capital movement systems, and technical know-how groups for leveraging entrepreneurial talent and accelerating the development of new companies (Kuratko \& LaFollette 1987). Hackett and Dilts (2004a, 2004b) define business incubation as shared services such as office-space facility that seeks to provide its incubatees with a strategic, value-adding intervention system of monitoring and business assistance.

Further, the authors defined several key words such as: innovation is the process of making change, difference, and novelty in the products, services, add value, and business practices to create economic and social benefit (EC, 2010). The OECD (2010) defines innovation as the implementation of a new or significantly improved product, service, process, a new marketing method, or a new organizational method in business practices, workplace organization, or external relations. Technology transfer can be defined as the development of technologies through research programs of universities including research tools and formal licensing of inventions and software (Hardy, 2010). A developed country can be defined as a highly developed economy, high industrial base with advanced technological infrastructure, and a high Human Development Index (O’Sullivan et al., 2003).

The knowledge based on an economy defined by Campbell and Carayannis (2014) is a process of economic learning to catalyze and accelerate the sustainability of economic growth.

The objective of this research is to analyze and identify the challenges and opportunities of innovation and incubator programs and their potential use worldwide. The remainder of the paper is as follows: "Literature review" provides a thorough review of the literature; in "Research methodology," the authors briefly discuss the research methodology used to facilitate the objectives; "Results" shows the findings of an international survey conducted by the authors; and "Conclusion" is the conclusion of the study.

\section{Literature review}

Many scholars discussed the importance of the incubator process (Al-Mubaraki, 2008; Bearse 1998a; Culp, 1996; Kuratko \& LaFollette 1987; Lumpkin \& Ireland, 1988; Merrifield, 1987). Also, Wagner (2006) confirmed the positive impact of business incubators on job creation. In addition, McAdam and McAdam (2008) indicated the most important element of incubators in the early stages is tangible incubator services and networking. Another study (Mian, 1996b) demonstrates the added value of incubator services including tangible services such as shared offices, assistance grants, marketing, accounting, university labs, and infrastructure.

Further, Smilor (1987), Campbell et al. (1985), and Merrifield (1987) indicated that several success factors from different perspectives such as: Community: entrepreneurial community support, networking, education, and linkage with university; Incubator: success indicators, finance, follow-up for incubatees, managerial support, clear policies of 
entry/exit; Incubatee: business awareness and success rate. Moreover, according to Cooper and Park (2008), incubators can be provided innovation through: (1) shaping entrepreneurs' market experience; (2) generating social capital; (3) providing information on the existence; and (4) availability of technological solutions.

Al-Mubaraki et al. (2014) identified the strength of incubators in developed and developing countries: (1) incubator dependence on the government as main sponsors to meet self-sustainability goals; (2) most incubators supporting the entrepreneur successfully through providing a wide range of services, focusing on intangible and intangible services; (3) developed countries indicated a high influence level of cultural indicators such as innovation, creativity, entrepreneurship digital growth, skills, and world-class education. However, in developing countries most cultural indicators were modest to low level. (4) In developing countries, the policy implication act strongly forms different perspectives such as government and university role in incubator management and funding; however, developing countries indicated a medium level of policy implication.

Al-Mubaraki et al. (2015a) concluded their study that successful implementation of the incubators and innovation programs can be expected to result in: (1) enhanced economic development through job creation; (2) a stronger entrepreneurship climate; (3) technology commercialization and transfer for graduated companies; (4) sustainability of graduated companies in the market with high rate of survival; (5) innovation acceleration with smart product and services; and (6) diversification of the economy from companies' outcomes such as innovation and technology.

Al-Mubaraki and Schrödl (2011) indicated a model for measuring the effectiveness of business incubation. This developed model supports the work of incubator managers, policy makers, researchers, practitioners, stakeholders, and government parties for the effective execution of business incubation enterprises. This model included four dimensions: (1) the number of businesses graduated over a period of time; (2) the number of businesses still in business over a period of time; (3) jobs created by incubator clients; and (4) salaries paid by incubator clients. In another study, Al-Mubaraki et al. (2012) concluded that the financial indicators are highest priority in ranking the incubators worldwide which reflect positive impact on the economic development in job creation.

Al-Mubaraki and Busler (2013) indicated that successful adaptation of innovation programs leads to: (1) a high rate of networking and outcomes; (2) high potential financing and strategic planning; (3) fostering entrepreneurship and innovation, research commercialization, and supporting technological entrepreneurship; (4) high number of jobs created; and (5) successful start-up companies with high survival rates. AlMubaraki and Busler (2010a, 2010b, 2010c) presented incubator guidelines such as incubators acting as sustainable dynamic models, fostering, supporting enterprise and innovation, and generating jobs. Al-Mubaraki, Muhammad, and Busler (2015b) recommended that innovation programs strengthen tools for the modern economy based on the knowledge towards smart growth. Al-Mubaraki and Busler (2014) concluded a study that incubators can be contributed to the international economy and could be played a vital role but also in smart and economic growth.

Some researchers have argued that incubator objectives can be summarized as follows: (1) economic growth; (2) commercialize technology and transfer; (3) fostering entrepreneurship climate; and (4) job creation (Abetti, 2004; Adegbite, 2001; Akçomak \& Taymaz, 2007; Allen and McCluskey, 1990; Allen \& Rahman, 1985; Al-Mubaraki, 
Table 1 Incubators: evidence from the literature

\begin{tabular}{|c|c|}
\hline Year & Citations, year of publication \\
\hline \multirow[t]{15}{*}{ 1988-2000 } & - Hisrich, 1988 \\
\hline & - Campbell et al., 1985 \\
\hline & - Smilor, 1987 \\
\hline & - Autio \& Kloftsen, 1998 \\
\hline & - Smilor, 1987 \\
\hline & - Smilor, 1987 \\
\hline & - Campbell et al., 1985 \\
\hline & - Merrifield, 1987 \\
\hline & - Culp, 1996 \\
\hline & - Lumpkin \& Ireland, 1988 \\
\hline & - Merrifield, 1987 \\
\hline & - Kuratko \& LaFollette, 1987 \\
\hline & - Bearse 1998a \\
\hline & - Allen \& Rahman, 1985 \\
\hline & - Campbell, 1989 \\
\hline
\end{tabular}

- Temali \& Campbell, 1984

- Plosila \& Allen, 1985

- Brooks, 1986

- Temali \& Campbell, 1984

- Allen \& Rahman, 1985

- Mian, 1994b

- Allen \& Rahman, 1985

- Fry, 1987

- Allen \& McCluskey, 1990

The value at the community level lies in a protected environment where new ventures are able to develop, provided by incubators, and this leads to economic growth and investment in local communities. Bls will be part of a larger economic development plan, and although incubator net job creation is low, it is still significant.

The focus of incubators could be a classification based on the nature of their primary sponsors or the focus of the incubatees. The key characteristics of incubators are low-priced rents, shared services, and the existence of entry/exit policies and university networking and support.

The benefits from the incubatee from the incubator's perspective include the importance of incubatees paying rent at below-market prices for office space, incubatees supporting each other, including purchasing, as each of the incubatees must have all aspects of business consulting services available to them. Incubatees in university technology businesses incubators are influenced positively by that environment.

Although $87 \%$ of entrepreneurs would have embarked on their enterprise, they agree on the usefulness of physical services, advertising and marketing, and risk management, insurance, and government grants that are available in an incubator.

There are several services offered by incubator management such as planning, for example, business planning, mission statements, strategic plans and budgets, and only half of the incubator managers participate in the planning process.

The occupancy rates show that 50\% of incubators do not present as real estate ventures. Incubators with established expertise are the most successful. Incubators whose focus is light manufacturing tend to have more success in job creation. Job creation and firms that have graduated were not significantly impacted by the business support services. 
Table 1 Incubators: evidence from the literature (Continued)

- Mian, 1996a

- Mian, 1996b

- Mian, 1997

- Autio \& Kloftsen, 1998

- Adegbite, 2001

- Shefer \& Frenkel, 2002

- Colombo \& Delmastro, 2002

- Hsu, Shyu, Yu, You, \& Lo, 2003

- Abetti, 2004

- Chan \& Lau, 2005

2001-2012 • Pena, 2004

- Lee \& Osteryoung, 2004
Tangible services such as shared offices are more successful. Less useful services include assistance grants, marketing, accounting, etc. Due to the availability of student employees, university labs, and infrastructure, a university's image is a significant benefit to incubator firms. Added value contributions are influenced by incubator services.

Within four years, firms' sales increased approximately tenfold and hiring increased fourfold. The university infrastructure offers many benefits such as employing students part-time and faculty consultations. Growth and survival of tenant firms are positively influenced by the provided university incubator services.

The four incubation programs indicate a high rate of sales and a high rate of employment (150\% and 35\%, respectively). A university's image enhances incubator firms and press coverage and university campus visits impact public attention. The most beneficial aspect for firms is the availability of student employees.

The analysis of success stories will be helpful in future implementation and practitioners should adopt the policies based on the landscape of the country.

The main goal of incubators is economic development, for example, in Switzerland, incubators are mostly privately owned.

The primary goals were not met in business or technology incubators. Insufficient support services and lack of objectivity in admission contributed to weaknesses in incubators operating under the Ministry and poor funding added to their organizational hardship.

In the last three years, $86.4 \%$ of the projects graduated from the program and the success rate shows that $78 \%$ obtained financial support after graduation. Managing the selection and overseeing of projects and the skills of the incubator are critical for success.

The incubator case studies in Italy represent highly skilled entrepreneurs. The case study shows no significant differences between on- and off-incubator firms regarding their innovative output. The outcomes were job creation, education, support of EU-sponsored projects, and networking.

In comparison, tenants in ITRI incubators are more satisfied than firms in other offices. The development of incubators is reflected in industrial development leading to economic development.

The study obtained survival rates of around $95 \%$ in Finland. The study shows the cost per job is $€ 6450$, with average sales growth rising by $160 \%$ per year during and after incubation. The government contribution will be less for funding incubators.

What are essential for entrepreneurs are rental subsidies for office space in addition to training programs. However, clustering does not benefit firms.

The significant impact of incubators will be reflected in high sales and employment growth. Most services offered by incubators have no impact on the performance indicators.

The comparative study between US and Korean respondents shows the role of incubator strategies such as goals, management, entry/exit policies, and business plans. The US respondents give more importance to these factors. The critical two factors are financial support and business networking. 
Table 1 Incubators: evidence from the literature (Continued)

- Peters, Rice \& Sundararajan, 2004

- Rothschild \& Darr, 2005

- Etzkowitz, Carvalho de Mello, \& Almedia, 2005

- Totterman \& Sten, 2005

- Rothaermel \& Thursby, 2005a

- Rothaermel \& Thursby, 2005b

-Wynarczyk \& Raine, 2005

- Von Zedtwitz \& Grimaldi, 2006

- Kim \& Ames, 2006

- Studdard, 2006

- Gassmann \& Becker, 2006

- Chandra and Fealey 2009

- Avnimelech, Schwartz, \& Bar-El, 2007
The rates for the graduation of companies are higher in incubators that offer coaching such as training, and in those that provide access to networking, e.g., consultants, scientists, customers, and other business firms. The number of graduation companies in the non-profit incubator type will be higher than in forprofit incubators.

Entrepreneurs' benefits from the incubators include reputation, credibility to the firm, and access to funding and business networking.

The incubators in Brazil create a low establishmentdevelopment cost and utilize the advantages of academic resources.

The incubator offered services such as support and networking. The incubator management team should focus on strategic business networking rather than on providing tangible services.

The failure rate will be decreased when linked to a university providing services such as licensed technology, faculty as senior management and informal links. The impact will affect the inventor positively.

This study focused on two mechanisms: transfer by a license to a university and backward citations of incubator firm patents to university patents or publications. The firm survival rate will be higher when holding a license. The firm absorptive capacity is measured by backward citations rather than firm performance.

The incubators play an active role in nurturing businesses and creating jobs. The managerial advisors' support will provide strong options for survival during the early stages of the start-up companies.

The relationship between the incubator objectives and incubator services should be clear to obtain the desired outcomes. The experience of the incubator manager is an essential support for the incubatee.

The qualifications of incubator managers should match with the requirements of the client companies such as support services and networking. Increments in incubator growth could negatively affect the success of incubators.

The incubator manager requires knowledge to interact with new product development, technological competence, and sales cost awareness. The firm's reputation requires increased credibility and marketing avenues.

In the incubator's initial phase, information flow is essential for both the incubator and the ventures. In the second phase, from the intangible services, knowledge comes from the for-profit incubators and the firms.

The government funds most large incubators and hightech-oriented incubators are dependent on government funding, which weakens their capability toward marketoriented incubation.

Closure rates for firms are less (19\% compared with $36 \%)$ for firms that received seed funding and were established in an incubator. The failure rate of VC firms is lower than for incubator firms. 
Table 1 Incubators: evidence from the literature (Continued)

- Aerts, Matthyssens,

\& Vandenbempt, 2007

- Hytti \& Maki, 2007

- Hughes et al., 2007

- McAdam \& Marlow, 2007

- Akçomak \& Taymaz, 2007

- McAdam \& McAdam, 2008

- Schwartz \& Hornych, 2008

2001-2012 • Frenkel et al., 2008

- Duff, 2004

- Chandra \& Fealey, 2009
The survival rate of tenants is positively correlated with the availability of a more balanced screening process. The screening process consists of market, financial, and management screening and it contributes positively with respect to failure rate. The critical role of incubators is to support the survival of the entrepreneurial spirit.

Younger firms demonstrate more growth-potential benefit from incubator services. However, older firms demonstrate less satisfaction with services. The tenancy duration for incubation must be optimal and flexible with respect to firm needs.

The study classified firms into four groups based on their capabilities, determination to access resources, to acquire knowledge, and strategic networking. The most critical aspect is strategic networking.

Of importance for tenants are the facilities offered by the incubator, its credibility, and networking opportunities. A critical factor is the trust that allows information exchange. In some cases, firms were hesitant in sharing sensitive information, such as secrecy and copying ideas, due to their close proximity to each other.

The main differences between on- and off-incubator firms are the sales and employment, but not innovation. The tangible services offered by incubators and funding can explain the differences.

The most important element of incubators in the early stages is tangible incubator services. Networking and clustering are the most important factors behind firm success.

The survival of media firms depends on the availability of specialized equipment and facilities including knowledge and know-how. The competition between companies in the same sectors leads to limitations in networking.

In the USA, private and public technology incubator firms promoted technological entrepreneurship among the immigrants in the USA and those from the former USSR. In private incubators, firms tend to benefit more from networking with international strategic partners and academia. However, the private incubator firms cannot fully replace public incubators.

This study looks in depth at eight case studies of leading $\mathrm{Bl}$ programs to provide a detailed appreciation of program design and incubator operations. Four of these programs are Australian and four are drawn from the United States.

The study finds that incubation programs that add value most effectively are those that adopt a pro-active business-development stance based on a sound appreciation of the business needs of their clients' characteristics in these pro-active, direct intervention systems.

This study describes the incubation landscapes of the United States, China, and Brazil, noting the similarities and differences in incubation approaches among the three countries. The key performance indicators for the comparison are based on the incubator's sponsorship/ financial model and its impact on strategy, its service mix with an emphasis on financial services, along with key environmental/contextual influences. The role of governments and their impact on incubator strategy in the three country contexts is discussed along with policy implications. 
Table 1 Incubators: evidence from the literature (Continued)

- Akçomak, 2009

- Atherton \& Hannon, 2006

- Schwartz and Hornych 2008

- Voisey, Gomall, Jones,

\& Thomas, 2006

- Al-Mubaraki \& Busler, 2010a

- Al-Mubaraki \& Busler, 2010b
Drawing lessons from country experiences, the appropriateness of incubators as a tool for entrepreneurship promotion in developing countries is assessed. The main weaknesses of incubators in developing countries are: (1) their focus on tangible services rather than intangible services; (2) their dependence on governments; (3) a lack of management and qualified personnel; and (4) a lack of incubator planning and creativity in solving problems.

Seven generic incubation strategies were identified and developed. Four focus on a premises-driven approach to incubation and three on a more process-based approach. All seven strategies represent opportunities for tailored, and hence, targeted approaches to the development of incubators and incubation services.

This study examines the survival of 352 firms from five German Bls after their graduation. The findings suggest that graduation causes an immediate negative effect on survivability that lasts up to three years after leaving the incubators. Furthermore, heterogeneous patterns of post-graduation exit dynamics between the Bls were observed. It was also found that performance during the incubation period is an indicator of the propensity for business closure after graduation.

The study finds that if incubation facilities are to receive continuing support, the measurement of success needs to be broader than a set of statistical outputs. Applications for public funding in support of Bls as part of an overall economic regeneration strategy should be able to provide a wider evaluation of effectiveness and the paper seeks to develop a model for this purpose to assist the ongoing development of incubator facilities in Wales.

The study indicated Bls can help young firms to survive and grow during their start-up years, and can play a key role in the economic development of a community or region. In developing countries, including Kuwait and the other GCC member states, Bls can be particularly valuable in helping to develop local economies, promote technology transfer, create new enterprises, and generate jobs. In addition, the survey results are used to make recommendations for how to maximize the success of incubators, including matching services offered to the needs of clients and involving a range of community stakeholders in the development of their programs. A number of options are proposed for developing and expanding the $\mathrm{BI}$ concept in Kuwait and the GCC member states.

Three practical business incubation European models are discussed based on their adoption as case study examples: the UK, France, and Germany. These three countries contain approximately $83 \%$ of all the incubators located throughout Europe today. This study focused on: (1) the nature of incubator financing; (2) the incubator's mission and strategy; and (3) graduation that it, in turn, offers its incubatee clients. The SWOT analysis of each case study reflects the strengths of each program and complies with its mission and objectives, showing great opportunity with the future plans and performance of each program. Bls contribute to the international economy and play a vital role not only in economic recovery, but also in economic development. International adaptation leads to the support of diverse economies, the commercialization of new technologies, job creation, and wealth building. In addition, more than 7000 incubation programs worldwide are engaged in supporting the development of new high-growth businesses. Today, Europe has funding in incubators with the goal of job creation and economic recovery. 
Table 1 Incubators: evidence from the literature (Continued)

- Al-Mubaraki \& Busler, 2011 b

- Al-Mubaraki \& Busler, 2011c

- Al-Mubaraki \& Busler, 2012b

- Al-Mubaraki, \& Busler, 2012c

- Al-Mubaraki, \& Schrödl, 2012a

- Al-Mubaraki \& Schrödl, 2012b
The case study of ten incubator organizations in developing countries is examined. The findings of this study indicate Bls are an effective and innovative tool for supporting start-up businesses. The empirical results highlight some implications for successfully developing and implementing the best practices of business incubation programs. This study makes a contribution to knowledge about the process of business incubation.

This paper is based on a mixed-methods approach. This study has clearly stated that business incubation is tool for economic development based on economic indicators from incubation outcomes such as: (1) entrepreneurs; (2) companies created; (3) jobs created; and (4) incubator companies. This is evident in both the United States and the developed countries, but is still taking shape in the developing countries such as the GCC member states.

The results show quantitative and qualitative responses used to determine success rates and key indicators of incubators in various countries. The best practice model based on the lessons learned from case studies indicates that the success of incubatees in terms of sustainable graduation is reliant upon: (1) clear objectives; (2) incubator location; (3) access to services; (4) employment creation; and (5) an economic development strategy. When accomplished, the best practice model can lead to a $90 \%$ survival rate for companies and reflects sustainability in the market.

The four strategic outcomes of the research findings are: (1) entrepreneurial climate (62\%) was the primary purpose of the incubator, (2) commercialization technologies stood at 55.5\%; (3) employment at 51.6\%; and (4) innovation and diversifying local economies at 46.1\%. The research adds value to the current literature on the sustainability of incubators and on outcomes. It provides a useful roadmap to both academicians and practitioners through experiences of worldwide incubator implementations.

The study proposed measurement models in the international context. The four measured indicators are: 1) the graduation of businesses that were incubated; (2) the success of businesses that were incubated; (3) jobs created by incubation; and (4) salaries paid by incubator clients. The recommendations from the study could help to develop business incubation guidelines for best practices in the GCC, which will lead to economic development worldwide and in the GCC.

The four dimensions discussed in the study determined the effectiveness of Bls individually and as an industry. The study recommended that:

1. Further research in this area should focus on the four dimensions discussed in this paper: (1) the number of businesses that have graduated over a period of time; (2) the number of businesses still in business over a period of time; (3) jobs created by incubator clients; and (4) salaries paid by incubator clients.

2. As the industry grows, new and existing incubators around the world should continue to track these measures of effectiveness in order to empirically demonstrate the value of business incubation.

3. Independent researchers, incubator funders, and governments should cooperate with practitioners in obtaining data related to these four measures of success. 
Table 1 Incubators: evidence from the literature (Continued)

- Al-Mubaraki \& Busler, 2012d

- Al-Mubaraki \& Busler, 2012e
The authors investigate the incubation models in

Europe and the Middle East. The study finding concludes that incubators play an important role in nurturing businesses, creating jobs, and producing high graduation rates of incubatee firms, especially from programs that offered strong tangible and intangible services. Within this landscape, incubator firms are able to achieve their primary goal of economic development, technology transfer, fostering entrepreneurship, and job creation.

This study has clearly stated that innovation programs are designed to accelerate the successful development of entrepreneurial companies through an array of business support resources and services. The adaptation leads to: (1) the age of the innovation program producing a high rate of networking and outcomes; (2) the government as a stakeholder giving high potential financing, strategic planning, and international marketing services; (3) a clear program goal fostering entrepreneurship and innovation, research commercialization, and support for technological entrepreneurship; (4) a high number of jobs being created, which leads to economic growth; and (5) advisory and mentoring services producing successful start-up companies with high survival rates.

2008; Al-Mubaraki and Busler, 2010a, 2010b, 2010c, 2011a, 2011b, 2011c, 2011d; Frenkel, Shefer, \& Miller, 2008; Hannon, 2005; Hansen, Chesbrough, Norhoa, \& Sull, 2000; Hughes et al. 2007; Lalkaka, 2002; McAdam \& McAdam, 2008; McAdam, Galbraith, McAdam, \& Humphreys, 2006; Mian, 1994a, 1994b, 1996a, 1996b, 1997; Phillips, 2002; Rothaermel \& Thursby, 2005a, 2005b; Smilor \& Gill, 1986; Sweeney, 1987; Thierstein \& Wilhelm, 2001).

Many international organizations serving business incubators in the United States, such as the National Business Incubation Association (NBIA, 2012), demonstrated the highest percentage of incubator characteristics such as: (1) incubator type indicated (54\%) as mixed-use type; (2) incubator goal includes job creation and fostering entrepreneurial climate; and (3) incubator services such as (i) help with business basics, (ii) high-speed Internet access, (iii) marketing assistance, and (iv) networking activities. Hughes et al. (2007) demonstrate that the successful firms' based on the strategic networking do not depend on the incubator tenancy period.

Lastly, Al-Mubaraki, Ahmed, and Al-Ajmei (2014) summarized the key findings of incubators in developed and developing countries. See Table 1.

\section{Research methodology}

The research methodology that has been used in this research study is a quantitative approach, such as international survey. The survey questionnaire is an appropriate tool for collecting quantitative data (Bryman, 2007). The authors in-depth experiences will be added value when selecting appropriate methods for data collection, data gathering, and data analysis. Furthermore, there are several reasons to use the quantitative approach, such as survey method: (1) when the information sought is reasonably specific and familiar to the respondents; and (2) when the researcher has knowledge of particular problems and the range of responses likely to emerge (Bryman, 2007). In addition, 


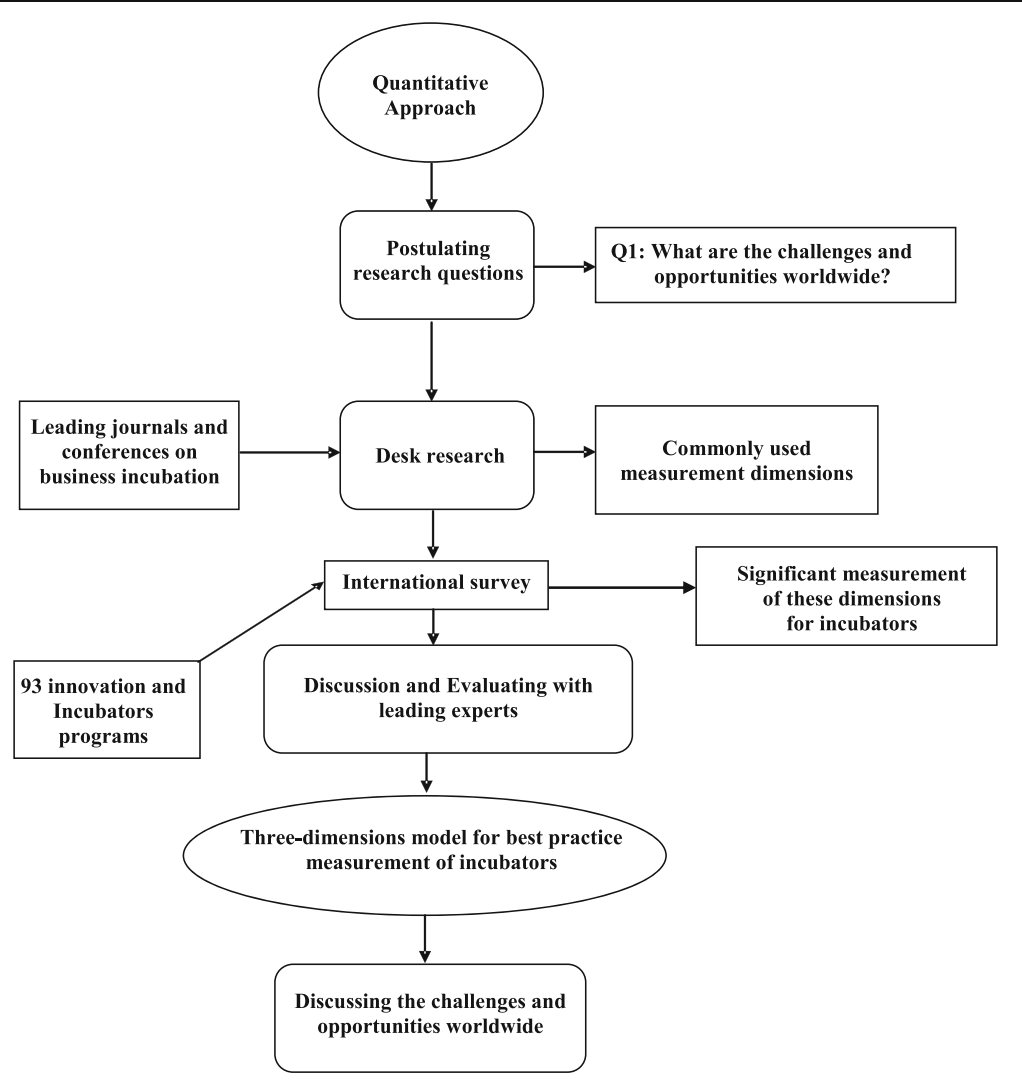

Fig. 1 The process of developing a research methodology

the survey consists of ten questions; each question was developed through refining the relevant questions to reach the study objectives. Furthermore, on SurveyMonkey, an online survey website, Internet-based surveys of business incubators and innovation programs were conducted with members of the National Business Incubation Association (NBIA), United Kingdom Business Incubation (UKBI), and United Kingdom Science Park Association (UKSPA). Moreover, the survey questionnaire will provide quantifiable information about three dimensions of incubators including incubators characteristics, incubators outcomes, and finical aspects. Figure 1 presents the research design.

There was a convenient sample of survey invitations: 200 selected programs as successful programs worldwide were emailed to NBIA, UKBI, and UKSPA members through the SurveyMonkey website; 107 were returned as undeliverable, leaving a sample frame of 93 . The total number of survey responses was 93, representing a response rate (RR) of approximately $47 \%$. The Statistical Package for the Social Sciences (SPSS) was used for statistical analysis and each question was used descriptive analysis.

Table 2 Highest response

\begin{tabular}{llll}
\hline No. & Survey questions & Highest response (\%) & \\
\hline 1 & Services of incubator & Strong tangible and specialized services & 67.0 \\
2 & Goals of incubator & Entrepreneurial climate & 73.0 \\
3 & Type of incubator & Technology incubators & 60.7 \\
\hline
\end{tabular}


Table 3 Lowest response

\begin{tabular}{lllr}
\hline No. & Survey questions & Lowest response (\%) & \\
\hline 1 & Services of incubator & Intangible & 5.7 \\
2 & Goals of incubator & Diversifying local economy & 40.4 \\
3 & Type of incubator & Manufacturing incubators & 6.7 \\
\hline
\end{tabular}

\section{Results and discussion \\ Survey results}

First dimension: incubator characteristics

Table 2 shows the highest percentage of incubator characteristic includes: (1) incubator services; (2) goals; and (3) type. The overview of the responses of 93 innovation centers and incubators in the survey sample. In addition, more than half (67.0\%) presented incubator goals of fostering an entrepreneurial climate. Furthermore, the highest services offered by incubators focused on strong tangible and specialized services (67.0\%). Finally, the majority $(60.7 \%)$ of incubators type focused on technology incubators.

Table 3 shows the lowest percentage of incubator characteristics includes: (1) incubator services; (2) goals, and (3) type. First, less than half (40.4\%) presented an incubator goal of diversification of local economy. Second, the lowest services offered by incubators focused on intangible services (5.7\%). Third, the manufacturing incubators type was the lowest (6.7\%).

\section{Second dimension: incubators outcomes}

Table 4 demonstrates highest incubators outcomes include: (1) number of jobs created; (2) number of graduate companies; (3) number of tenants; and (4) survival rate. First, most incubators created more than 50 jobs per incubator program (63.2\%). Second, less than half (36.0\%) had graduated in the range of 6-25 companies. Third, the highest of the programs reported that the number of tenants inside the incubation program was in the range of 6-25 (48.3\%). Fourth, less than half $(47.7 \%)$ indicated that the survival rate for the companies was in the range of $81-90 \%$.

Table 5 shows lowest incubator outcomes include: (1) number of jobs created; (2) number of graduate companies; (3) number of tenants; and (4) survival rate. First, the lowest incubation programs created less than five jobs per year (9\%). Second, less than half $(30.2 \%)$ had graduated in the range of 1-5 companies per year. Third, lowest of the programs reported that the number of tenants inside the incubation program was in the range of $1-5(16.1 \%)$. Fourth, the survival rate for the companies indicated less than $80 \%$ per year $(26.1 \%)$.

\section{Third dimension: financial}

Table 6 shows the overview of highest incubators financial data includes: (1) annual turnover growth; (2) incubator income; and (3) growth of revenue. First, the majority

Table 4 Highest response

\begin{tabular}{llll}
\hline No. & Survey questions & Highest response (\%) & \\
\hline 1 & Jobs created from the incubator $(\mathrm{n})$ & $>50$ & 63.2 \\
2 & Graduate companies from incubator $(\mathrm{n})$ & $6-25$ & 36.0 \\
3 & Tenants inside the incubator (n) & $6-25$ & 48.3 \\
4 & Survival rate of tenants (\%) & $81-90$ & 47.7 \\
\hline
\end{tabular}


Table 5 Lowest response

\begin{tabular}{llll}
\hline No. & Survey questions & Lowest response (\%) & \\
\hline 1 & Jobs created from the incubator $(\mathrm{n})$ & $1-5$ & 9 \\
2 & Graduate companies from incubator $(\mathrm{n})$ & $1-5$ & 30.2 \\
3 & Tenants inside the incubator & $1-5$ & 16.1 \\
4 & Survival rate of tenants (\%) & $<80$ & 26.1 \\
\hline
\end{tabular}

(54.4\%) of annual turnover growth for most programs indicated less than $\$ 999,000$. Second, more than half (50.6\%) of revenue presented less than $\$ 999,000$. Third most of the program income was indicated as low income (44.2\%).

Table 7 shows the overview of lowest incubators finical data includes: (1) annual turnover growth; (2) incubator income; and (3) growth of revenue. First, the lowest (9.1\%) of annual turnover growth for most programs responded in the range of \$5-10 million. Second, less than one-quarter $(20.9 \%)$ of revenue presented as high. Third, lowest response of the program was indicated as high income (5.9\%).

Table 8 shows the ranking dimensions of incubators include three dimensions, with incubator goals such as entrepreneurial climate indicating the highest ranking followed by second rank of incubator services including strong tangible and specialized services. This was followed by the third rank as number of jobs created was over 50 jobs per year. In addition, the fourth rank was technology incubator types and the fifth rank was annual turnover growth less than $\$ 1$ million dollars. The sixth rank was growth of revenue less than \$1 million dollars and the seventh rank indicated the number of tenants inside the incubator as less than 25 companies per year. Furthermore, the eighth rank was survival rate $<90 \%$, the ninth rank was incubator income, and the last rank was number of graduate companies from incubators at less than 25 companies per year.

The evidence from another study (NBIA, 2007) indicated that the vital goals of incubation programs are job creation, engaging the entrepreneurial climate, diversifying local economies, and accelerating growth in a local industry. In their study, Thierstein and Wilhelm (2001) stated that the main goal of incubators is economic development. The National Business Incubation Association (NBIA, 2009) demonstrated that the most popular incubator type was technology incubators, targeted by entrepreneurs, which included several tangible services: (1) physical infrastructure; (2) management support; (3) technical support; (4) access to finance; (5) legal services; and 6) networking. The most important element of incubators in the early stages is tangible incubator services, such as networking and clustering, which are the most important factors behind firm success (McAdam \& McAdam, 2008).

Furthermore, the study by Abetti (2004) indicated that survival rates of around 95\% inside the incubators reflect the importance of firms in joining the program of incubations. The study shows that the cost per job is $€ 6450$, with average sales growth rising by $160 \%$ per year during and after incubation. Another study by Wynarczyk and Raine

Table 6 Highest response

\begin{tabular}{llll}
\hline No. & Survey questions & Highest response (\%) & \\
\hline 1 & Incubator income & Low & 44.2 \\
2 & Annual turnover growth & $\$ 100,000-999,000$ & 54.4 \\
3 & Growth of revenue & $\$ 100,000-999,000$ & 50.6 \\
\hline
\end{tabular}


Table 7 Lowest response

\begin{tabular}{lllr}
\hline No. & Survey questions & Lowest response (\%) & \\
\hline 1 & Incubator income & High & 5.9 \\
2 & Annual turnover growth & $\$ 5-10 \mathrm{M}$ & 9.1 \\
3 & Growth of revenue & $\$ 5-10 \mathrm{M}$ & 20.9 \\
\hline
\end{tabular}

(2005) indicated that incubators play an active role in nurturing businesses, creating jobs, and increasing survival rates during the early stages of the start-up companies. Another study by Peters et al. (2004) showed that the rates of the graduation of companies are higher in incubators through offering coaching, and that the number of graduation companies in the non-profit incubator type will be higher than in for-profit incubators.

\section{Conclusion}

Incubators and innovation programs have become an important topic worldwide and have contributed positively to economic growth. This paper is based on quantitative methods such as international survey, which provided a deeper insight and understanding into the phenomenon under investigation. The selection of programs was made from successful incubators and innovation centers worldwide.

In addition, the descriptive analysis of the survey results in a convenient sample of 93 incubators and innovation programs worldwide with a response rate of about $47 \%$, which leads to the adaptation of incubators and innovation programs worldwide.

The study indicated two challenges: (1) incubator models indicated as high technology incubator types contributed positively to the extension of technology sectors in each country with new product and new services; and (2) fostering and supporting enterprise and innovation to create the best environment for growth of businesses to start-up and accelerate smart growth.

However, the two opportunities could indicate that: (1) the sustainability of incubation and innovation programs is based on the high survival rate (81-90\%) of small- or medium-sized firm per fiscal year; and (2) the sustainability of incubation and

Table 8 Ranking dimensions

\begin{tabular}{|c|c|c|c|c|}
\hline No. & Survey questions & Highest response (\%) & & Rank \\
\hline \multicolumn{5}{|c|}{ First dimension: incubator characteristics } \\
\hline 1 & Incubator services & Strong, tangible, and specialized services & 67.0 & 2 \\
\hline 2 & Incubator goals & Entrepreneurial climate & 73.0 & 1 \\
\hline 3 & Incubator type & Technology incubators & 60.7 & 4 \\
\hline \multicolumn{5}{|c|}{ Second dimension: incubator outcomes } \\
\hline 1 & Jobs created from the incubator (n) & $>50$ & 63.2 & 3 \\
\hline 2 & Graduate companies from incubator $(n)$ & $6-25$ & 36.0 & 10 \\
\hline 3 & Tenants inside the incubator $(n)$ & $6-25$ & 48.3 & 7 \\
\hline 4 & Survival rate of tenants (\%) & $81-90$ & 47.7 & 8 \\
\hline \multicolumn{5}{|c|}{ Third dimension: financial } \\
\hline 1 & Incubator income & Low & 44.2 & 9 \\
\hline 2 & Annual turnover growth & $\$ 100,000-999,000$ & 54.4 & 5 \\
\hline 3 & Growth of revenue & $\$ 100,000-999,000$ & 50.6 & 6 \\
\hline
\end{tabular}


innovation programs is based on the high jobs creation over 50 jobs per year and high number of graduate and client companies of around 25 companies per year.

In conclusion, the successful adaptation of the incubators and innovation programs leads to high outcomes when reaching a higher stage of economic growth based on the development of the number of graduate companies, client companies with high survival rates, and high added value for innovative products and services, as well as fostering an entrepreneurship environment, and commercializing technology transfer. This evidence comes from worldwide successful implementations in developed and developing countries.

\title{
Methods
}

To determine the challenges and opportunities, an international survey was completed. This is an appropriate tool for collecting quantitative data that can be summarized and analyzed to reach valid conclusions. This method is generally utilized to gather specific information is familiar to the respondents. The questions found the survey on were developed through refining the relevant questions.

\section{Acknowledgements}

The project team would like to express their genuine appreciation to the Kuwait Foundation for Advancement of Sciences (KFAS) for the financial support provided for the project (2012-1103-01). A special acknowledgment and appreciation is due to Prof. Rashed Al-Ajmei, Dean of College of Business Administration, Kuwait University and Chairman of Center for Excellences for all managerial advice and support required for the project. The team also thanks the National Business Incubation Association (NBIA) and United Kingdom Business Incubation (UKBI) for providing successful international case studies to be interviewed.

\section{Funding}

Self-funding.

\section{Author's contributions}

This work was carried out in collaboration between both the authors. HM designed the study, managed the literature searches, and collected the survey results. MB wrote the introduction and prepared the first draft of the manuscript. Both authors read and approved the final manuscript.

\section{Competing interests}

The authors declare that they have no competing interests.

\begin{abstract}
About the authors
Dr. Hanadi Mubarak Al-Mubaraki is an Assistant Professor at Kuwait University. She teaches management courses for undergraduates and graduates. She has published scientific articles in many academic journals, and one book, and has presented her research papers in many countries. Dr. Al-Mubaraki is the recipient of several international awards and medals for her contribution to International Scientific Research International Peace Prize-UN for Achievement and Masters Degree Honour Medal 1996-Kuwait University from HH Sheikh Jaber Al-Ahmed Al-Sabah, the Amir of Kuwait. Dr. Al-Mubaraki serves on the Editorial Board of international journals. She has substantial experience in research entrepreneurship in D.C., Economic Development, Incubators, innovation, and S.D.

Dr. Michael Busler is a Professor of Finance, Finance Track Coordinator at Stockton University, USA. He teaches undergraduate courses in Finance and Game Theory as well as Managerial Economics and Corporate Finance in the MBA Program. He has been published in eight different academic journals and has presented his research in ten countries. In addition, he has worked as a Financial Analyst for the Ford Motor Company and FMC Corporation and has been an entrepreneur having owned several businesses, mostly in the Real Estate development field. He earned his Doctorate at Drexel University.
\end{abstract}

\section{Publisher's Note}

Springer Nature remains neutral with regard to jurisdictional claims in published maps and institutional affiliations.

Received: 20 December 2016 Accepted: 7 June 2017

Published online: 24 July 2017

\section{References}

Abetti, P. A. (2004). Government-supported incubators in the Helsinki Region, Finland: Infrastructure, results, and best practices. Journal of Technology Transfer, 29(1), 19-40.

Adegbite, O. (2001). Business incubators and small enterprise development: the Nigerian experience. Small Business Economics, 17(3), 157-66. 
Aerts, K., Matthyssens, P., \& Vandenbempt, K. (2007). Critical role and screening practices of European business incubators. Technovation, 27(5), 254-67.

Akçomak, I.S. (2009). Incubators as tools for entrepreneurship promotion in developing countries, UNU-WIDER and UNU-MERIT research workshop on entrepreneurship, Technological Innovation, and Development held in Maastricht, the Netherlands, 30-31 October 2008

Akçomak, I. S., \& Taymaz, E. (2007). Assessing the effectiveness of incubators: the case of Turkey. In V. V. Ramani \& A. V. Bala Krishna (Eds.), Business Incubation: An Introduction (pp. 234-64). Hyderabad: Icfai University Press.

Allen, D. N., \& McCluskey, R. (1990). Structure, policy, services and performance in the business incubator industry. Entrepreneurship, Theory and Practice, 15(2), 61-77.

Allen, D., \& Rahman, S. (1985). Small business incubators: a positive environment for entrepreneurship. Journal of Small Business Management, 23(July), 12-22

Al-Mubaraki, H. (2008). Procurement of International Business Incubation- Quantitative and Qualitative approaches. Ely, England: Melrose Books.

Al-Mubaraki, H., \& Busler, M. (2010a). Business incubators models of the USA and UK: A SWOT analysis. World Journal of Entrepreneurship, Management and Sustainable Development, 6(4), 335-354

Al-Mubaraki, H., \& Busler, M. (2010b). Business incubators: Findings from worldwide survey, and guidance for the G.C.C. States. Global Business Review, 11(1), 2010

Al-Mubaraki, H., \& Busler, M. (2010c). Sustainable development through the inclusion of business incubators: A SWOT Analysis. World Sustainable Development Outlook, pp. 51-63. www.worldsustainable.org

Al-Mubaraki, H., \& Busler, M. (2011a). The development of entrepreneurial companies through business incubator programs. International Journal of Emerging sciences, 1(2), 95-107

Al-Mubaraki, H., \& Busler, M. (2011b). Innovation, entrepreneurship, job creation, based on incubators: international experience. The Ninth Biennial Conference on Entrepreneurship, 16-18 February 2011, Ahmedabad, India

Al-Mubaraki, H., \& Busler, M. (2011c). The development of entrepreneurial companies through business incubator programs. International Journal of Emerging Sciences, 1(2), 95-107

Al-Mubaraki, H., \& Busler, M. (2011d). The incubators economic indicators: mixed approaches. Journal of Case Research in Business and Economics, 4. http://www.aabri.com/manuscripts/11884.pdf

Al-Mubaraki, H., \& Busler, M. (2012b). Quantitative and qualitative approaches of incubators as value-added: best practice model. The Journal of American Academy of Business, Cambridge, 18, 2012

Al-Mubaraki, H., \& Busler, M. (2012c). Road map of international business incubation performance. Journal of International Business and Cultural Studies, 6. http://www.aabri.com/manuscripts/121120.pdf.

Al-Mubaraki, H., \& Busler, M. (2012d). A comparative study of incubators landscapes in the Europe and Middle East. European Journal of Business and Management, 4(10). http://iiste.org/Journals/index.php/EJBM/issue/view/208

Al-Mubaraki, H., \& Busler, M. (2012e). Fostering the innovation and entrepreneurship in developing countries. International Journal of Innovative Research in Management, 1, 67-73

Al-Mubaraki, H., \& Busler, M. (2013). Fostering the innovation and entrepreneurship in developing countries. International Journal of Innovative Research in Management, 1(1), 67-73.

Al-Mubaraki, H., \& Busler, M. (2014). Incubator successes. World Journal of Science, Technology and Sustainable Development, 11(1), 44-52.

Al-Mubaraki, H., \& Schrödl, H. (2011). Measuring the effectiveness of business incubators: a four dimensions approach from a Gulf Cooperation Council perspective. Journal of Enterprising Culture, 19(4), 435-452.

Al-Mubaraki, H., \& Schrödl, H. (2012a). Incubating success towards Gulf Cooperation Council (GCC). International Journal of Innovation and Knowledge Management in Middle East \& North Africa, 1(2), 31-56

Al-Mubaraki, H., \& Schrödl, H. (2012b). Measuring the effectiveness of business incubators: a four dimensions approach from a Gulf Cooperation Council perspective. Journal of Enterprising Culture, 19(4), 435-452

Al-Mubaraki, H., Al-Sharrah, G., \& Aruna, M. (2012). Ranking business incubation: mathematical techniques. International Journal of Innovation and Regional Development, 4(6), 466-487. http://www.inderscience.com/browse/index. php?journallD=234.

Al-Mubaraki, H., Ahmed, A., \& Al-Ajmei, R. (2014). Best practices of business incubators in developed and developing countries: the roadmap for the Gulf Cooperation Council (GCC) countries. University of Sussex, England: World Association for Sustainable Development

Al-Mubaraki, H., Muhammad, A., \& Busler, M. (2015a). Innovation and entrepreneurship powerful tools for a modern knowledge-based economy. Springer Publishers, www.springer.com

Al-Mubaraki, H., Muhammad, A., \& Busler, M. (2015b). Measuring innovation: the use of indicators in developed countries. World Journal of Entrepreneurship, Management and Sustainable Development, 11(3).

Atherton, A., \& Hannon, P. D. (2006). Localised strategies for supporting incubation: Strategies arising from a case of rural enterprise development. Journal of Small Business and Enterprise Development, 13(1), 48-61.

Autio, E., \& Kloftsen, M. (1998). A comparative study of two European business incubators. Journal of Small Business Management, 36(1), 30-43.

Avnimelech, G., Schwartz, D., \& Bar-El, R. (2007). Entrepreneurial high tech development policy: Israel's experience with two policy instruments. European Planning Studies, 15(9), 1181-1198.

Bearse, P. (1998a). A question of evaluation: NBIA's impact assessment of business incubators. Economic Development Quarterly, 12(4), 322-333

Brooks, O. J. (1986). Economic development through entrepreneurship: incubators and the incubation process. Economic Development Review, 4(2), 24-29.

Bryman, A. (2007). Qualitative data analysis. London, UK: SAGE Publications.

Campbell, C. (1989). Change agents in the new economy: Business incubators and economic development. Economic Development Review, 7(2), 56-59.

Campbell, D. F. J., \& Carayannis, E. G. (2014). Explaining and comparing quality of democracy in quadruple helix structures: the quality of democracy in the United States and in Austria, challenges and opportunities for development. In E. G. Carayannis, D. F. J. Campbell, \& M. P. Efthymiopoulos (Eds.), Cyber-development, cyber- 
democracy and cyber-defense. challenges, opportunities and implications for theory, policy and practice (pp. 117-148). New York, NY: Springer. http://link.springer.com/chapter/10.1007/978-1-4939-1028-1_4.

Campbell, C., Kendrick, R. C., \& Samuelson, D. S. (1985). Stalking the latent entrepreneur: business incubators and economic development. Economic Development Review, 3(2), 43-49.

Chan, K. F., \& Lau, T. (2005). Assessing technology incubator programs in the science park: the good, the bad and the ugly. Technovation, 25(10), 1215-1228.

Chandra, A., \& Fealey, T. (2009. Business incubation in the United States, China and Brazil: A comparison of role of government, incubator funding and financial services. international journal of entrepreneurship: Special Issue, 13, 67-86. Accessed on July 27, 2016 from ABI/INFORM Global. (Document ID: 1980050591).

Colombo, M. G., \& Delmastro, M. (2002). How effective are technology incubators: Evidence from Italy. Research Policy, 31(7), 1103-1122.

Cooper, S. Y., \& Park, J. S. (2008). The impact of 'incubator' organizations on opportunity recognition and technology innovation in new, entrepreneurial high-technology ventures. International Small Business Journal, 26(1), 27-56.

Culp, R. (1996). A test of business growth through analysis of a technology business incubator. Ph.D. Dissertation. Atlanta, GA: Georgia Institute of Technology.

Duff, A. (2004). Best practice in incubator management. http://www.eifn.ipacv.ro/include/documentations_files/ bestpracrpt.pdf. Accessed 20 February 2016

EC (European Commission). (2002). Benchmarking of Business Incubators, Final Report. Brussels

EC (European Commission). (2010). EUROPE 2020: A strategy for smart, sustainable and inclusive growth. http://ec. europa.eu/eu2020/pdf/COMPLET\%20EN\%20BARROSO\%20\%20\%20007\%20\%20Europe\%202020\%20\%20EN\%20version.pdf. Accessed 5 January 2016/

Etzkowitz, H., Carvalho de Mello, J. M., \& Almeida, M. (2005). Towards "meta-innovation" in Brazil: the evolution of the incubator and the emergence of a triple helix. Research Policy, 34(4), 411-24.

Frenkel, A., Shefer, D., \& Miller, M. (2008). Public versus private technological incubator programmes: privatizing the technological incubators in Israel. European Planning Studies, 16(2), 189-210.

Fry, F. L. (1987). The role of incubators in small business planning. American Journal of Small Business, 12(1), 51-61.

Gassmann, O., \& Becker, B. (2006). Towards a resource-based view of corporate incubators. International Journal of Innovation Management, 10(1), 19-45.

Hackett, S., \& Dilts, D. M. (2004a). The real options-driven theory of business incubation. Journal of Technology Transfer, 29(1), 41-54

Hackett, S., \& Dilts, D. M. (2004b). A systematic review of business incubation research. Journal of Technology Transfer, $29(1), 55-82$

Hannon, P. (2005). Incubation policy and practice: building practitioner and professional capability. Journal of Small Business and Enterprise Development, 12(1), 57-78.

Hansen, M. T., Chesbrough, H., Norhoa, N., \& Sull, D. (2000). Networked incubators: Hothouses of the new economy. Harvard Business Review, 74-84.

Hardy, R. (2010). Report of COUNCIL ON GOVERNMENTAL RELATIONS. Available online: http://www.cogr.edu/sites/ default/files/21_Questions_Paper.pdf

Hisrich, R. D. (1988). New business formation through the enterprise development center: a model for new venture creation. IEEE Transactions on Engineering Management, EM-35(4), 221-231.

Hsu, P. H., Shyu, J. Z., Yu, H. C., You, C. C., \& Lo, T. S. (2003). Exploring the interaction between incubators and industrial clusters: the case of the ITRI incubator in Taiwan. R\&D Management, 33(1), 79-90.

Hughes, M., Ireland, R. D., \& Morgan, R. E. (2007). Stimulating dynamic value: social capital and business incubation as pathway to competitive success. Long Range Planning, 40, 154-77.

Hytti, U., \& Maki, K. (2007). Which firms benefit most from the incubators? International Journal of Entrepreneurship and Innovation Management, 7(6), 506-523.

InfoDev. (2009). Mixed-use Incubator Handbook: A Start-up Guide for Incubator Developers, JBV 2002. Lesson 17: Business incubators. www.jbv.com/lessons/lesson17. Accessed 5 January 2016.

Kim, H., \& Ames, M. (2006). Business incubators as economic development tools: rethinking models based on the Korea experience. International Journal of Technology Management, 33(1), 1-24.

Kuratko, D. F., \& LaFollette, W. R. (1987). Small business incubators for local economic development. Economic Development Review, 5(2), 49-55.

Lalkaka, R. (2002). Technology business incubators to help build an innovation-based economy. Journal of Change Management, 3(2), 167-176.

Lee, S. S., \& Osteryoung, J. S. (2004). A comparison of critical success factors for effective operations of university business incubators in the United States and Korea. Journal of Small Business Management, 42(4), 418-26.

Lumpkin, J. R., \& Ireland, R. D. (1988). Screening Practices of New Business Incubators: The Evaluation of Critical Success Factors. American Journal of Small Business, 12(4), 59-81.

McAdam, M., \& Marlow, S. (2007). The university incubator: insights in the entrepreneurial process from a network perspective. International Journal of Entrepreneurial Behavior and Research, 14(4), 270-285.

McAdam, M., \& McAdam, R. (2008). High tech start-ups in university science park. incubators: the relationship between the start-up's lifecycle progression and use of the incubator's resources. Technovation, 28(5), 277-90.

McAdam, M., Galbraith, B., McAdam, R., \& Humphreys, P. (2006). Business processes and networks in university incubators: a review and research agendas. Technology Analysis and Strategic Management, 18(5), 451-72.

Merrifield, D. B. (1987). New business incubators. Journal of Business Venturing, 2, 277-284.

Mian, S. A. (1994a). Are university technology incubators providing a milieu for technology-based entrepreneurship? Technology Management, 1, 86-93

Mian, S. A. (1994b). U.S. university-sponsored technology incubators: an overview of management, policies, and performance. Technovation, 14(8), 515-528

Mian, S. A. (1996a). Assessing the value-added contributions of university technology business incubators to tenant firms. Research Policy, 25, 325-35 
Mian, S. A. (1996b). The university business incubator: a strategy for developing new research/technology-based firms. Journal of High Technology Management Research, 7, 191-208

Mian, S. A. (1997). Assessing and managing the university technology business incubator: an integrative framework. Journal of Business Venturing, 12, 251-285.

NBIA (National Business Incubation Association). (2007). Suggested Metrics. NBIA: A Toolkit. www.nbia.org/impact/ suggested_metrics.php. Accessed 9 January 2016

NBIA (National Business Incubation Association). (2009). What is Business Incubation? Accessed 11 January 2016.

NBIA (National Business Incubation Association). (2012). State of the business incubation industry. Athens, Ohio: NBIA Publications.

O'Sullivan, A., \& Sheffrin, S. M. (2003). Economics: Principles in action. Upper Saddle River, NJ: Pearson Prentice Hall.

OECD (Organisation for Economic Co-operation and Development). (1997). Technology incubators: nurturing small firms. Paris: Organisation for Economic Co-Operation and Development.

OECD (Organisation for Economic Co-operation and Development). (2010). Ministerial report on the OECD Innovation Strategy. Innovation to strengthen growth and address global and social challenges key findings. http://www.oecd. org/document/7/0,3343,en_2649_201185_44222919_1_1_1_1,00.html.

Pena, I. (2004). Business incubation centers and new firm growth in the Basque Country. Small Business Economics, 22(3-4), 223-36.

Peters, L., Rice, M. P., \& Sundararajan, M. (2004). The role of incubators in the entrepreneurial process. Journal of Technology Transfer, 29(1), 83-91.

Phillips, R. G. (2002). Technology business incubators: how effective as technology transfer mechanism? Technology in Society, 24, 299-316.

Plosila, W., \& Allen, D. N. (1985). Small business incubators and public policy: implications for states and local development strategies. Policy Studies Journal, 13, 729-734.

Rothaermel, F. T., \& Thursby, M. (2005a). Incubator firm failure or graduation? The role of university linkages. Research Policy, 34(7), 1076-1090

Rothaermel, F. T., \& Thursby, M. (2005b). University-incubator firm knowledge flows: assessing their impact on incubator firm performance. Research Policy, 34(3), 305-320

Rothschild, L., \& Darr, A. (2005). Technological incubators and the social construction of innovation networks: an Israeli case study. Technovation, 25, 59-67.

Schwartz, M., \& Hornych, C. (2008). Specialization as strategy for business incubators: an assessment of the central German multimedia center. Technovation, 28, 436-449.

Shefer, D., \& Frenkel, A. (2002). An evaluation of the Israeli Technological Incubator Program and its projects. Israeli Financing Instruments for the Support of Entrepreneurship

Smilor, R. W. (1987). Managing the incubator system: critical success factors to accelerate new company development. IEEE Transactions on Engineering Management, EM-34(4), 146-156.

Smilor, R. W., \& Gill, M. D. (1986). The new business incubator: linking talent, technology, capital, and know-how. Massachusetts: Lexington Books.

Studdard, N. L. (2006). The effectiveness of entrepreneurial firm's knowledge acquisition from a business incubator. International Entrepreneurship and Management Journal, 2, 211-25.

Sweeney, G. P. (1987). Innovation, entrepreneurship and regional development. London: Francis Pinter.

Temali, M., \& Campbell, C. (1984). Business incubator profiles: a national survey. Minneapolis, MN: University of Minnesota, Hebert H. Humphrey Institute of Public Affairs.

Thierstein, A., \& Wilhelm, B. (2001). Incubator, technology and innovation centres in Switzerland: features and policy implications. Entrepreneurship and Regional Development, 13(4), 315-31.

Totterman, H., \& Sten, J. (2005). Start-ups: business incubation and social capital. International Journal of Small Business, 23, 487-511.

UKBI (United Kingdom Business Incubation). (2007). What is business incubation? http://www.ukbi.co.uk. Accessed 28 May 2016.

Voisey, P., Gornall, L., Jones, P., \& Thomas, B. (2006). The measurement of success in a business incubation project. Journal of Small Business and Enterprise Development, 13(3), 454-468.

Von Zedtwitz, M., \& Grimaldi, R. (2006). Are service profiles incubator-specific? results from an empirical investigation in Italy. Journal of Technology Transfer, 1(4), 459-468.

Wagner, K. V. (2006). Business development incubator programs! An Assessment of performance in Missouri. A Dissertation presented in partial fulfilment of the requirement for the degree of Doctor of philosophy. Capeila University

Wynarczyk, P., \& Raine, A. (2005). The performance of business incubators and their potential development in the north east region of England. Local Economy, 20(2), 205-220.

Submit your manuscript to a SpringerOpen ${ }^{\mathcal{O}}$ journal and benefit from:

- Convenient online submission

- Rigorous peer review

- Open access: articles freely available online

- High visibility within the field

- Retaining the copyright to your article

Submit your next manuscript at $\gg$ springeropen.com 